\title{
前立腺癌初期治療における内分泌併用化学療法の検討
}

\author{
久留米大学医学部泌尿器科学教室 (主任 : 江藤耕作教授) \\ 松岡啓吉武信行野口 正典 \\ 田中 英裕 野田 進士 江藤 耕作
}

\section{CLINICAL EVALUATION OF THE USEFULNESS OF ENDOCRINE THERAPY COMBINED WITH CHEMOTHERAPY AS AN INITIAL TREATMENT FOR PROSTATIC CANCER}

\author{
Kei Matsuoka, Nobuyuki Yoshitake, Masanori Noguti, Hidehiro Tanaka, \\ Sinsi Noda and Kosaku Eto \\ Department of Urology, School of Medicine Kurume University
}

(Director: Prof. K. Eto)

We evaluated the usefulness of endocrine therapy combined with chemotherapy as an initial treatment in comparison with endocrine therapy alone in 100 patients with prostatic cancer treated at the Department of Urology, Kurume University between 1978 and 1987.

The 5-year and 8-year survival rates in all patients were 46.4 and $24.1 \%$, respectively.

The response rates (partial response and stable in NPCP criteria) 3 months after the initiation of the therapy were $93.3 \%$ in the group receiving endocrine therapy combined with chemotherapy and $92.6 \%$ in the group receiving endocrine therapy.

Though the survival rates within 3 and a half years were slightly higher in the group treated with endocrine therapy combined with chemotherapy, no significant difference was observed between the two groups during the entire period. However, the outcome was significantly better in the groups showing partial response 3 months after the initiation of the therapy $(\mathrm{p}<0.01)$ and showing stable condition $(\mathrm{p}<0.05)$ than in the group showing progression. These results suggest that the proximity effects affect the prognosis.

In the group treated by endocrine therapy combined with chemotherapy, cisdichlorodiammine platinum, cyclophosphamide, or adriamycin, as the drug combined with diethylstilbestrol diphosphate, tended to produce better results than estracyt $1-3$ years after the treatment.

\footnotetext{
要旨：久留米大学病院泌尿器科において，1978年より1987年までの 10 年間に加療した新鮮前立腺癌症例 100例について, 初回治療としての内分泌併用化学療法の有用性について, 内分泌療法と比較して検討し た.

全症例の 5 年生存率は $46.4 \%$ で, 8 年生存率は $24.1 \%$ であった.

治療開始後 3 カ月に打ける response rate（NPCP-stable 以上）は, 内分泌併用化学療法群で $93.3 \%$, 内分泌療法群で $92.6 \%$ と，両群ともに良好な成績であった。

内分泌併用化学療法群の生存率においては，3年半までは内分泌療法群よりも若干良好な傾向であっ たが, 全期間を通じて有意差は認められなかった。しかし，近接効果で progression であった群に比較し て, partial response 群 $(\mathrm{p}<0.01)$ と stable 群 $(\mathrm{p}<0.05)$ では有意に予後が良く, 近接効果は予後に 反映されることが示唆された.

内分泌併用化学療法群に㧍いて, diethylstilbestrol diphosphate に併用する薬剤としては, estracyt よ り cis-dichlorodiammine platinum, cyclophosphamide, adriamycin 等を使用した方が $1 \sim 3$ 年で予 後が良い傾向にあった。
} 


\section{緒言}

前立腺癌の治療で困惑させられることは，初期には 内分泌療法に良く反応しても，治療の経過と共に内分 泌療法抵抗性となり，不幸な転帰をとる症例が多いこ とである。このような再然癌に対する化学療法の試み については，多くの報告があり有用性も認められてい る.

再燃は，前立腺癌細胞の多種性にも，その原因が求 められているので, 治療初期から内分泌療法に化学療 法を併用すれば，混在する内分泌非依存性癌細胞を減 少させ，予後を改善させることができると考兄られる。 今回著者らは，前立腺癌初期治療に打ける内分泌併用 化学療法の意義について, 同時に施行した内分泌単独 療法を対照として検討したので報告する。

\section{対象と方法}

1978 年より 1987 年 6 月までの約 10 年間に, 久留米大 学病院泌尿器科で入院加療を受けた前立腺癌109例の 内, 病理組織学的検索が十分に行なわれた再燃癌を除 く初回治療の 100 例を対象とした. 対象の年龄は 46〜92 歳, 平均70.1歳であった。臨床病期は, $\mathrm{A} ： 8$ 例 $\left(\mathrm{A}_{1}\right.$ ： 4 例, $\mathrm{A}_{2}: 4$ 例), $\mathrm{B}: 18$ 例 ( $\mathrm{B}_{1}: 3$ 例, $\mathrm{B}_{2}: 15$ 例), $\mathrm{C}: 20$ 例， $\mathrm{D}: 54$ 例 $\left(\mathrm{D}_{1}: 6\right.$ 例, $\mathrm{D}_{2}: 48$ 例) で $\mathrm{C}$ と D が $74 \%$ を占めていた。組織学的には，高分化腺癌 32 例, 中分化腺癌 24 例, 低分化腺癌 26 例, 分化度分類不明 18 例であった。

これら100例に対して施行した治療の内訳を表 1 に 示した。治療の主体となったものは，治療 1 の除臭術 に加えて diethylstilbestrol diphosphate (以下 DES) を投与した内分泌療法37例と, 治療 4 に示した様に, これに，さらに化学療法を加光た内分泌併用化学療法 46例であった。化学療法剤としては, cis-dichloro diammine platinum (以下 CDDP), cyclophos phamide (以下 CPM), adriamycin (以下 ADM), pepleomycin (以下 PLM), 5-fluorouracil(以下5-FU) 等を単剂または併用で使用した。また， estramustine sodium phosphate (以下ECT) は，取扱い規約に従い 化学療法剤として扱った。表 1 に示す治療 2 と治療 5

表 1 当科で施行した治療法の内訳

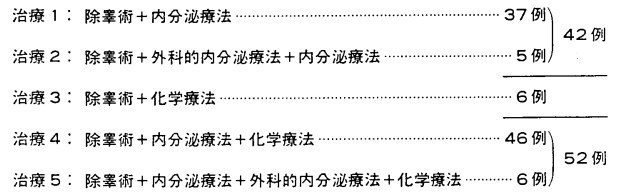

に抢ける外科的内分泌療法とは，左副腎静脈中結腸静 脈吻合術と右副腎摘除術で, 治療 2 の 5 例と, 治療 5 の 6 例に施行している. 今回は, 内分泌療法群として 治療 1 と治療 2 の 42 例, 内分泌併用化学療法群として 治療 4 と治療 5 の52例を比較検討した.

各薬剂は，投与量や投与間隔について統一した基準 による使用はしなかったが，原則として以下に示すよ らに投与した。基本となった $\mathrm{DES}$ は, $500 \mathrm{mg} /$ day を 1 $\sim 2$ 週静注し，その後 $200 \sim 300 \mathrm{mg} /$ day の内服にて維 持した。併用した化学療法は, ECT では $560 \mathrm{mg} / \mathrm{day} の$ 内服で, CDDP, CPM, ADM 等の ECT 以外の化学療 法剤は，単独または併用にて DES の導入時期または 内服に変更した時期に, 静注で $1 \sim 3$ 週毎, 最低 3 コー ス使用した。

各治療の近接効果は, 治療開始 3 力月後に, NPCP criteria $^{1)}$ に基づいて評価した。生存率の算出は, Kaplan-Meier 法を, 生存率曲線の有意性の検定は, generalized Wilcoxon test を用いた。尚, 臨床病期や 組織学的分類は, 泌尿器科・病理前立腺癌取扱い規約 ${ }^{21}$ に従った。

\section{結 果}

全症例の生存率を図 1 に示した。 3 年生存率は $62.9 \%, 5$ 年生存率は $46.4 \%, 8$ 年生存率は $24.1 \%$ で あった。

1. 臨床病期（以下 stage）と生存率

stage A の 5 年生存率は $64.3 \%$, stage B は $55.9 \%$, stage Cは31.1\%, stage D $44.8 \%$ であり，C，Dの 予後は極めて悪かった。 しかし, stage A D の各生存 率曲線の間に有意差は認められなかった（図 2 ).

2. 分化度と生存率

分化度別の 5 年生存率は, 高分化型 $71.9 \%$, 中分化

図 1 全症例の生存率

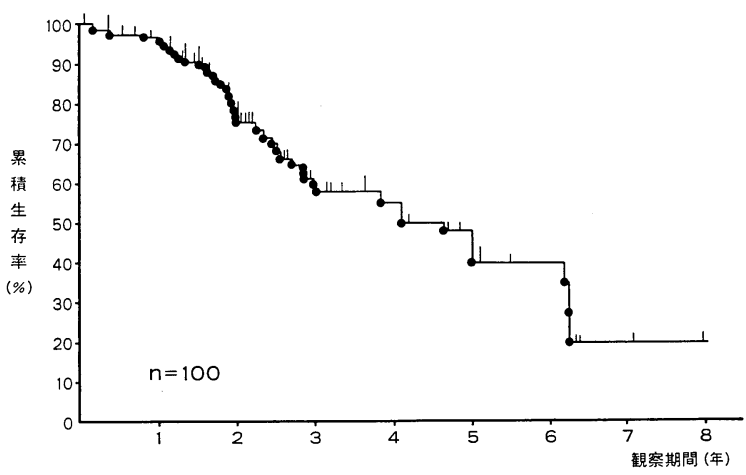


図 2 臨床病期別生存率

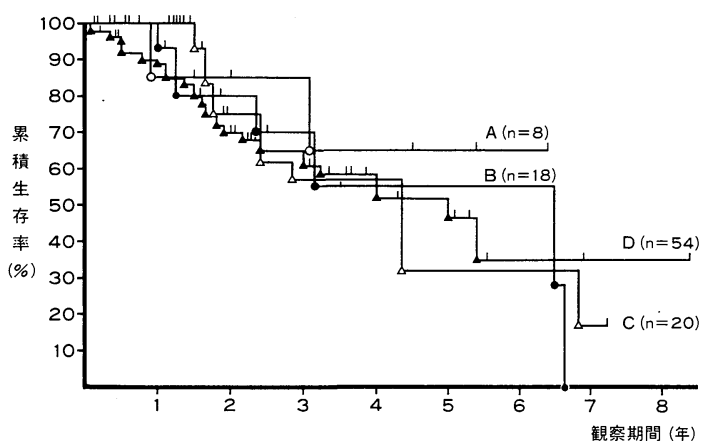

図 3 組織型別生存率

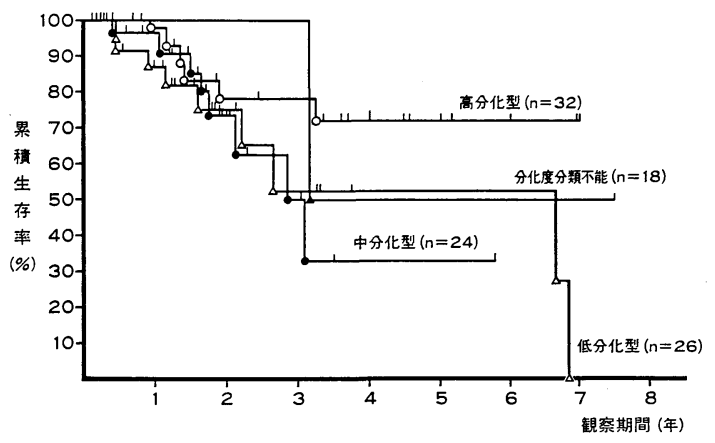

図 4 内分泌療法之内分泌併用化学療法

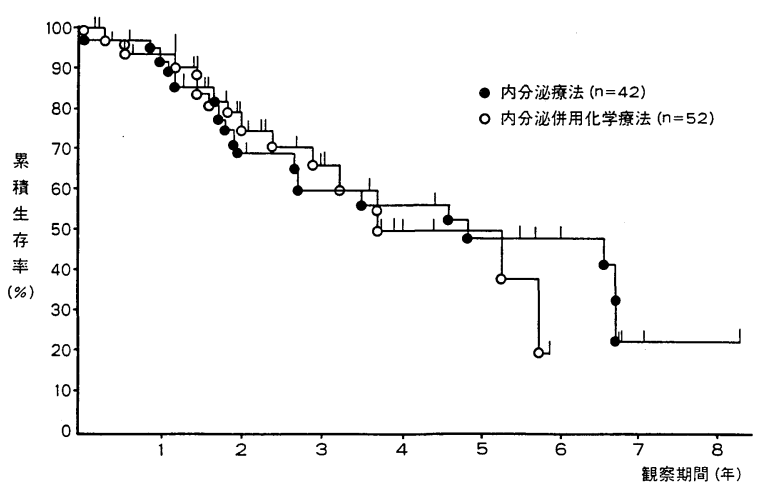

型 $33.6 \%$ ，低分化型 $53 \%$ と，5年生存率においては高 分化型に比較して中, 低分化型が予後が悪い傾向に あったが，各生存率曲線の間に有意差は認められな かった（図 3 ).

3. 治療法と近接効果

治療開始 3 力月後に拈ける近接効果が評価可能で あったのは, 内分泌療法群27例, 内分泌併用化学療法 群30例であった。前者では, partial response 8 例, stable 17例, progression 2 例, 後者では, それぞれ15 例, 13例, 2 例で, response rate は, 内分泌療法群 $92.6 \%$, 内分泌併用化学療法群 $93.3 \%$ と, いずれも良 好な成績で, 両群の差を認めなかった。

\section{4. 治療法と生存率}

内分泌療法群 42 例と, 内分泌併用化学療法群52例に ついて生存率を検討した。内分泌療法群の 5 年生存率 は49.3\%, 内分泌併用化学療法群は37.9\% と, 後者の 方が悪い傾向にあったが，両群の生存率曲線には有意 差は認められなかった（図 4 ）.

次に,この 2 群を背景因子別に検討した。

i) 臨床病期

stage A 8 例であり, 内分泌療法群（6 例）の 1 年および 3 年生存率は，それぞれ75\%，37.5\%であり， 内分泌併用化学療法群 (2 例) のそれはいずれも $100 \%$ であった. 3 年から 4 年の時期における生存率に打い ては, 内分泌併用化学療法群の方が有意 $(\mathrm{p}<0.05)$ に 予後が良かったが，生存率曲線の検定に扣いては有意 差を認めなかった. stage Bにおける, 内分泌療法群 （ 7 例）の 1 年生存率， 3 年生存率はいずれも $100 \%$ で あり, 内分泌併用化学療法群(10例)では $100 \%$ と $34.3 \%$ であった． 3 年の時点では，内分泌㞠法群の方が有意 $(\mathrm{p}<0.05)$ に生存率が良かったが，両群の生存率曲線 の検定において有意差を認めなかった（図 5 ). stage C に打ける内分泌療法群 (13例) と内分泌併用化学療法 群 ( 7 例) では， 2 年から 2 年半の間においては内分

図 5 臨床病期 $\mathrm{AB}$ に招ける内分泌療法と内分泌併用化学療法の生存率
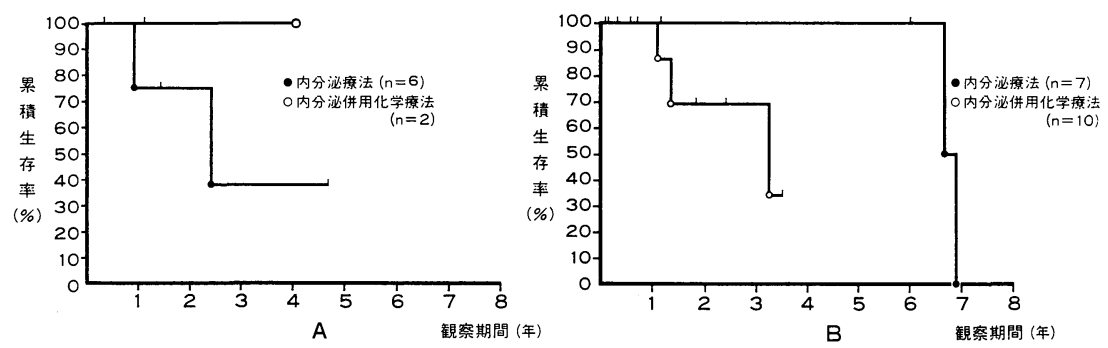
因 6 臨床病期 C, D に打ける内分泌療法と内分泌併用化学療法の生存率
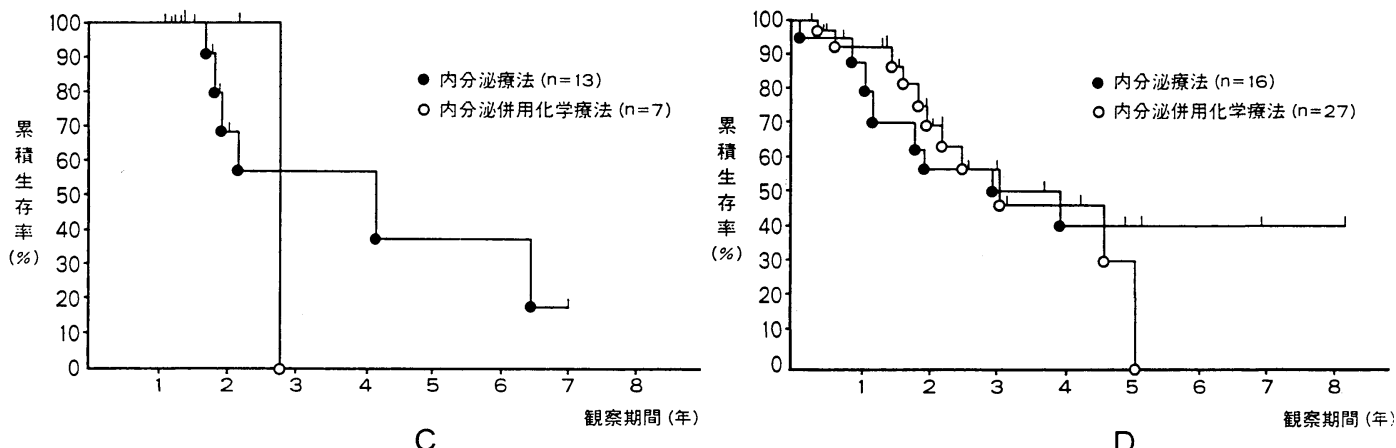

図 7 各分化型腺癌に括ける内分泌療法と内分泌併用化学療法の生存率

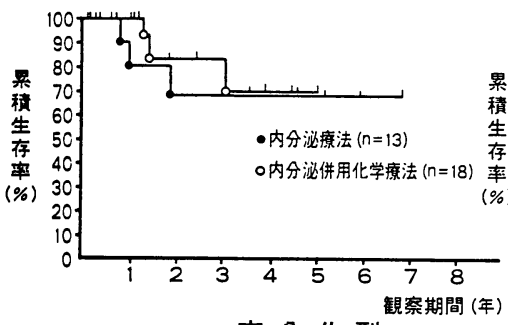

高分化型

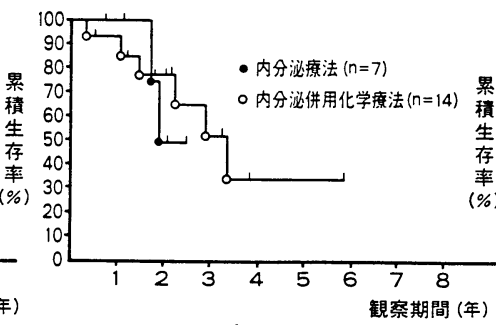

中分化型

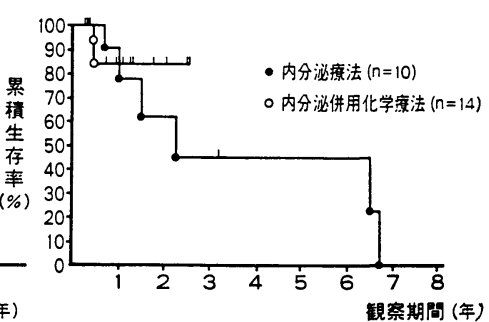

低分化型
泌併用化学療法群の方が有意 $(\mathrm{p}<0.05)$ に生存率が良 かったが，5年生存率では, 内分泌療法群 $36.9 \%$, 内 分泌併用化学療法群 $0 \%$ と内分泌療法群が良好な傾向 にあった。しかし，生存率曲線の検定では両群間に有 意差を認めなかった. stage Dにおける内分泌療法群 （16例）と内分泌併用化学療法群 (27例) の 5 年生存率 は, $40.38 \%, 31.38 \%$ であり, 生存率曲線の検定にお いても有意差を認めなかった（図 6 ).

ii）分化度

高分化型においては, 1 年から 3 年において内分泌 併用化学療法群 (18例) の方が内分泌療法群 (13例) より予後が良い傾向にあったが，5年生存率では $68.6 \%, 69.4 \%$ で，両群の生存率曲線においても有意 差が認められなかった。中分化型においても，2 年か ら 3 年までは, 内分泌併用化学療法群 (14例) の方が 内分泌㞠法群（7例）より良い傾向にあったが，生存 率曲線の検定においては有意差を認めなかった。低分 化型に沶いては， 1 年から 3 年までは内分泌併用化学 療法群（14例）が内分泌療法群（10例）に比較し, 予 後が良い傾向にあったが，生存率曲線の間には有意差 は認められなかった（図 7 )。

4. 内分泌併用化学療法群に打ける近接効果と生存
図 8 近接効果別生存率

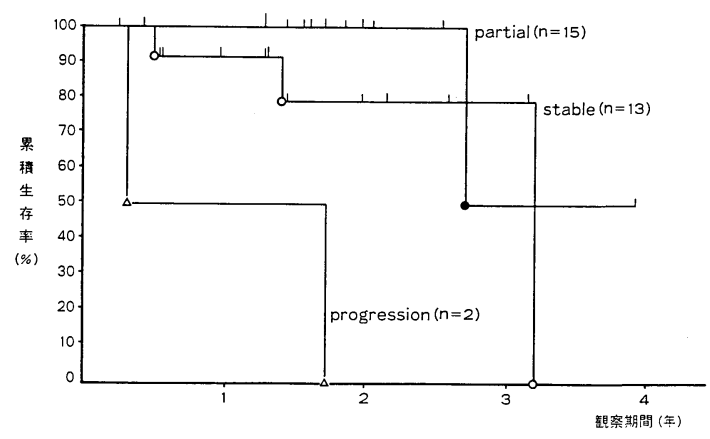

率

治療開始から 3 力月後における近接効果が判明した 30例について, 効果別に生存率を検討してみた。 partial response を示した15例の 1 年生存率は $100 \%$ で, 3 年生存率は $50 \%$ であり, stable 13例では, $92.3 \%$, $79.1 \%$ で, progression 2 例では $50 \%$ ，0\%であった。 各生存率曲線の検定では, partial response 群と, stable 群の間には有意差は認められなかったが, progression 群に比較して, partial response 群 $(\mathrm{p}<0.01)$ と stable 群（p<0.05）では有意に予後が良かった（図 
図 9 内分泌併用化学療法群に颃ける薬剤別生存率

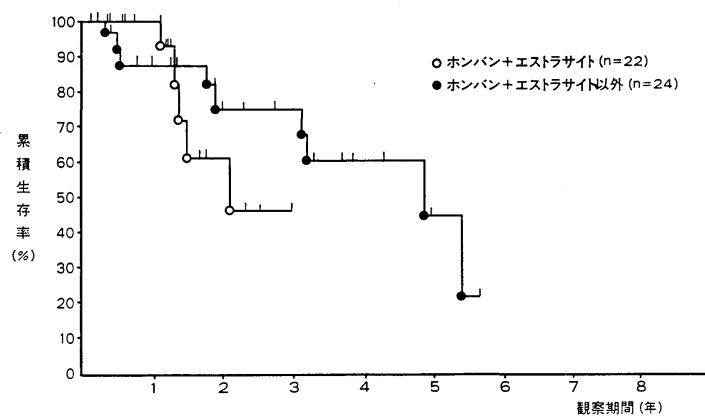

$8)$.

\section{5, 薬剂と生存率}

内分泌併用化学療法群に括忊る併用薬剂について, ECT (22例) と ECT 以外 (24例) に分け予後を検討し てみた。 ECT 群の 1 年生存率は $100 \%, 3$ 年生存率は $46.4 \%$ で, ECT 以外群のそれらは87.1\%と60.7\%で あった。 1 年半以後においては ECT 以外群の予後が 良い傾向にあったが，生存率曲線の検定に拈いては有 意差は認められなかった（図 9 ）。

\section{考 察}

前立腺癌患者の初診時での臨床病期を，本邦報告例 に打いてみると，C と D の症例が52.5\% 77\% (3) 7) と， 初診時すでに進行した患者が大部分を占めている。著 者らの成績も同様であり，これが前立腺癌患者の予後 を悪くしている原因の一つであろう。しかし，臨床病 期別の 5 年生存率(すべて実測生存率)では，A で $68 \%$ 〜 100\%, B で36.1\% 67\%, C で41.9\% 69\%, D で $24.3 \%$ 36\% と報告3) 7)され，Dは明らかに予後が悪 いが，Bは C と同じく予後が悪く，また A の生存率に も，B や C と同様に大きな差が認められている。われ われの成績においても，A：64.3\%，B：55.9\%，C： $31.1 \%, \mathrm{D}: 44.8 \%$ と各病期別の生存率曲線の間には genaralized Wilcoxon test による有意差は認められ なかった。このように諸家の報告において，とくに $\mathrm{B}, \mathrm{C}$ の 5 年生存率に大きな差が認められる理由とし て, 明らかに予後が違う $\mathrm{A}_{1}, \mathrm{~A}_{2}$ の substaging の方法 や, 両者の比率の問題, さらに staging pelvic lymphadenectomy の試み象 ${ }^{80}$ により明らかにされつ つある staging error が主な要因であろらと考兄られ た。

分化度別の 5 年生存率では, 高分化型 $54.7 \%$ ～56\%, 中分化型 $53.4 \% \sim 64 \%$, 低分化型 $12.7 \%$ ～44\% と報 告3) 7)され, 低分化型の予後は悪い.われわれの成績で
は, 高分化型：71.9\%, 中分化型：33.6\%, 低分化型： $53 \%$ と中, 低分化型の予後は, 有意ではないが悪い傾 向にあった。

このように臨床病期や分化型は, 前立腺癌の予後を 左右する大きな因子であろらと考兄られるが，再燃も また治療効果に大きな影響を与えている。すなわち， 自験例でもそうであったが, 殆どの前立腺癌は初回内 分泌療法によく反応し, 内分泌㞠法は前立腺癌に対す る治療の中心的役割を担ってきている.しかしながら， 治療の継続とともに内分泌療法に抵抗を示し, 再燃す る癌はしばしば経験される. 再燃の機序は, 前立腺癌 構成細胞の heterogeneity ${ }^{1112)} に よ り$ 説明されている. このような再燃癌に対しては, もはや内分泌療法の効 果は期待できないということで, CPM, 5-FU, ADM, MTX, CDDP 等の化学療法剤の有効性が報告されて いる ${ }^{13) ~ 16)}$. また, これら化学療法剤の併用に関する検 討も多く, 薬剂の組合せとしては, $\mathrm{CPM}+\mathrm{ADM}^{17)}$, $\mathrm{CPM}+\mathrm{MTX}+5-\mathrm{FU}^{15)}$, Ifosfamide $+\mathrm{VCR}+\mathrm{PEP}^{19)}$, $\mathrm{CPM}+\mathrm{ADM}+\mathrm{CDDP}^{1820)}$ などがある。化学療法の多 剤併用は単剂使用よりは若干効果が勝っているようで あるが，組合せによっては併用による利点がないとす る報告もあるので注意が必要である。例えば，Torti ら 21) は，37例の転移を有するホルモン抵抗性前立腺癌 に $\mathrm{ADM}$ 単独と ADM と CDDP の組合せのランダマ イズドスタディから, ADM と CDDP の併用は ADM 単独に比較し, 有効性, 有効期間, 生存率に叔いて, なんら勝ることはなかったと報告している。さらに Soloway ら ${ }^{221}$ は, ECT と vincristine の併用では, $\mathrm{ECT}$ 単独投与よりも効果が悪いと報告しているよう に, 併用による効果は必ずしも期待できるわけではな い.

化学療法剤による諸種治療は, 現状ではまだ再燃癌 を十分コントロールできるまでには至っていないま た，再燃は内分泌療法に抵抗性となったと考兄られる にもかかわらず，化学療法剂を単独で使用したときよ りも内分泌療法を併用した方が効果がある場合もあ

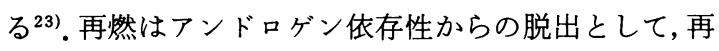
燃の原因としての副腎性アンドロゲンの増加の概念に は否定的な意見 ${ }^{24)}$ もあるが, 外科的副腎摘除 ${ }^{25)}$ や我々 の行なっている外科的内分泌療法 ${ }^{26) 27}$, 下垂体摘除 ${ }^{28)}$ もしくは, aminoglutethimide ${ }^{29)}$ fulutamide ${ }^{301}$ とよ り効果が著明に認められる症例も多く経験されてお り，副腎性アンドロゲンは再燃因子の 1 つであろらと いら考えを捨てきれないでいる，今回は前立腺癌の多 
面性, 寸なわち内分泌療法依存性細胞と非依存性細胞 の混在を前提として, 著者らは初回治療より, 内分泌 療法に化学療法を併用すれば，予後の改善が期待でき るのではないかと考光, 種々の化学療法を併用してき た。このよらな試みは最近になり散見されるように なった. Mukamel ら ${ }^{311}$ は, 除辠術 $+\mathrm{DES}+5-\mathrm{FU}+$ CPM にて 25例の stage D の $84 \%$ に原発巣が50\%以上 縮小し，骨スキャンで64\%に改善を認めたことを報告 している. Servadio ら ${ }^{32}$ は, 同様の症例で, さらに生 存率を検討したところ 5 年生存率は $63.4 \%$ で, 除殬術 やDES 単独使用の成績より優れていることを報告し た. 神田ら ${ }^{33)}$ は ECT を化学内分泌療法として使用し, 藤井ら ${ }^{34)}$ は DES, ECT, prostal のそれぞれにCPMを 併用し, 碓井ら ${ }^{35}$ ) は除鼻術に CDDP か ADM を併用, 倉本ら ${ }^{36)}$ は DES と ECT, DES と CDDP とて検討し, 初回治療に拈ける内分泌併用化学療法の有用性が報告 されている. しかし，これらは近接効果のみの結果で あり，本法が生存に対してどれだけの効果を及ぼして いるのか明確にされていないのが見状である. 生存率 の比較においては, 竹内 ${ }^{37}$ の報告がある.これによると gestagen と5-FU の連日投与群は, hexestrol 連日投与 群よりも, 有意差はないが生存率では常にすぐれてい たと報告している。また, NPCP-プロトコール500¹)に おける検討に扔いては, DES+CPM や ECT+CPM の組合せと, DES や除辠術単独のものと比較し, $12 \mathrm{~W}$ 後の objective response は両者似たようなものであっ たが，化学療法を併用したものは内分泌単独よりも全 体的に生存率が改善したことを報告している。われわ れの検討に打ける, 内分泌療法群, 内分泌併用化学療 法群の近接効果は両者とも $90 \%$ 以上で良好であった。 しかし, 生存率についてみると, 5 年生存率では内分 泌併用化学療法群の方が悪い傾向にあったが, 全期間 を通じて両群間に有意差は認められなかった。また各 臨床病期や分化型における検討に打いても，ある期間 に扣いては内分泌併用化学療法群の方が良い時期もあ るが，これも全体を通して両群の間には有意差は認め られなかった。このよらに, 今回得られた結果は当初 予想していた期待どおりのものではなかった。この理 由として, 併用薬剤や投与量の問題, ならびに投与対 象因子の関与, すなわち retrospective な検討であっ たことも原因の一つではないかと考えられたが, NPCPの prospective study に扔いても, 両群の生存 率に顕著な差が認められていない事実より, 前立腺癌 初回治療に打ける併用化学療法の意義については, 今
後さらに, 種々の試みによって解決されるべき問題で あろらと考学られた。

内分泌併用化学療法群の治療開始後 3 カ月に打ける 近接効果と生存率の関係に括いては, progression 群 に比較して partial response 群と stable 群では有意 に予後が良い結果であった，今回は，検討した症例数 が少なく，また基準となる薬剤の組合せを選択してい ないので結論を出すには，さらに検討が必要と考兄ら れるにしても, 近接効果の上がる薬剤の組合せを検討 し，選択していくことが予後の改善につながることが 示唆され，今後は統一した基準に扎いて検討する予定 である。また，内分泌併用化学療法群に打ける併用薬 剂の種類については, 症例数の関係から ECT と ECT 以外に分け，予後を検討した。 この結果, 生存率の比 較に怙いて有意ではなかったが，ECT 併用群よりも ECT 以外の薬剤を併用した方が予後が良い傾向に あったが，これについてもさらに検討が必要と考兄ら れた。

\section{結 語}

当科にて入院加療し, 病理組織学的検索が十分行な われた前立腺癌100例に捛いて, 初回より施行した内分 泌併用化学療法が生存にどのような影響を与えるか, 同時に施行した内分泌療法群と比較検討した。

内分泌併用化学療法群の生存率は，3 年までは内分 泌療法群よりも若干良好な傾向を示したが，全期間を 通じて有意差を認めなかった。しかし，近接効果は予 後を反映していることが示唆され，今後は近接効果の ある薬剤の組合せにより予後を改善することが重要な ことと考えられた。

\section{文献}

1) Schmidt, J.D., Scott, W.W., Gibbons, R., Johnson, D.E., Prout, G.R. Jr., Loening, S., Soloway, M., deKernion, J., Pontes, J.E., Slack, N.H. and Murphy, G.P.: Chemotherapy programs of the National Prostatic Cancer Project (NPCP). Cancer, 45, 1937-1946, 1980.

2) 日本泌尿器科学会, 日本病理学会編: 泌尿器科・病 理前立腺癌取扱い規約. 第 1 版. 金原出版, 東京, 1985.

3) 内田豊昭, 本田直康, 横田真二, 青 輝昭, 池田 滋, 小田島邦男, 真下節夫, 遠藤忠雄, 石橋 晃, 小柴 健：前立腺癌の臨床統計的観察. 泌尿紀要, 33, 869-876, 1987.

4）山本 明, 湯浅 誠, 今川章夫, 香川 征, 黒川一 男：前立腺癌の臨床的検討. 泌尿紀要, 33, 2050 $-2054,1987$. 
5）藤目 真, 鈴木 明, 星野十, 中村晃一郎, 岩動 孝一郎, 新島端夫：前立腺癌の治療成績. 日泌尿会 誌, 77, 711-715, 1986.

6）横関秀明, 滝川 浩, 香川 征, 黒川一男：前立腺 癌の臨床的検討. 西日泌尿, 48, 336-344, 1986.

7) 福谷恵子, 三方律治, 武内 巧, 河邊香月, 横山正 夫：前立腺癌の治療成績一ホルモン療法を中心と して一。 日泌尿会誌，78，1821-1826，1987.

8) Brendler, C.B. Cleeve, L.K., Anderson, E.E. and Paulson, D.F.: Staging pelvic lymphadenectomy for carcinoma of the prostate: Risk versus benefit. J. Urol., 124, 849-850, 1980.

9) Catalona, W.J. and Stein, A.J.: Staging erros in clinically localized prostatic cancer. J. Urol., 127, 452-456, 1982.

10）布施秀樹, 座間秀一, 秋元 晋, 島崎 淳, 松菩 理, 村上信乃, 五十嵐辰男 : 前立腺癌の staging pelvic lymphadenectomy. 泌尿紀要, 32, 1465 -1470, 1986.

11) Murphy, G.P., Beckley, S., Brady, M.F., Chu, T. M., deKernion, J.B., Dhabuwala, C., Gaeta, J.F., Gibbons, R.P., Loneing, S.A., Mckiel, C.F., McLeod, D.G., Pontes, J.E., Prout, G.R., Scardrino, P.T., Schlegel, J.U., Schmidt, J.D., Scott, W.W., Slack, N.H. and Soloway, M.S. : Treatment of newly diagnosed metastatic prostate cancer patients with chemotherapy agents in combination with hormones versus hormones alone. Cancer, 51, 1264-1272, 1983.

12）島崎 淳, 布施秀樹, 座間秀一：前立腺癌. 癌の臨 床, 31, 1195-1201, 1985.

13) Scott, W.W., Gibbons, R.P., Johnson, D.E., Prout, G.R., Schmidt, J.D., Chu, T.M., Gaeta, J. F., Joiner, J.R., Saroff, J. and Murphy, G.P. : Comparison of 5-fluorouracil (NSC-19893) and cyclophosphamide (NSC-26271) in patients with advanced carcinoma of the prostate. Cancer Chemother. Rep., 59, 195 201, 1975.

14) Schmidt, J.D., Scott, W.W., Gibbons, R.P., Johnson, D.E., Prout, G.R. Jr., Loening, S.A., Soloway, M.S., Chu, T.M., Gaeta, J.F., Slack, N.H., Saroff, J. and Murphy, G.P.: Comparison of procarbazine, imidazole-carboxamide and cyclophosphamide in relapsing patients with advanced carcinoma of the prostate. J. Urol., 121, 185-189, 1979.

15) Herr, H.W.: Cyclophosphamide, methotrexate and 5-Fluorouracil combination chemotherapy versus chloroethylcyclohexy-Nitrosourea in the treatment of metastatic prostatic cancer. J. Urol., 127, 462-465, 1982.

16) Loening, S.A., Beckley, S., Brady, M.F., Chu, T.
M., DeKernion, J.B., Dhabuwala, C., Gaeta, J.F., Gibbons, R.P., Mckiel, C.F., Mcleod, D.G., Pontentes, J.E., Prout, G.R., Scardino, P.T., Schlegel, J.U., Schmidt, J.D., Scott, W.W., Slack, N.H., Soloway, M.S. and Murphy, G.P. : Comparison of estramustine phosphate, methotrexate and cis-platinum in patients with advanced, hormone refractory prostate cancer. J. Urol., 129, 1001-1006, 1983.

17) Ihde, D.C., Bunn, P.A., Cohen, M.H., Dunnick, N.R., Eddy, J.L. and Minna, J.D.: Effective treatment of hormonal ly-unresponsive metastatic carcinoma of the prostate with adriamycin and cyclophosphamide. Cancer, 45, 1300 $-1310,1980$.

18）布施秀樹, 座間秀一, 秋元 晋, 島崎 淳: 前立腺 癌再燃例に対する cyclophosphamide, adriamycin, cis-platinum 併用療法. 西日泌尿, 48, 1553 -1556, 1986.

19）吉本 純：再燃 Stage D 前立腺癌に対する Vincristine, Ifosfamide, peplomycin 併用療法. 西日 泌尿, 44, 418-421, 1982.

20) Al-Sarraf, M.: Combination of cytoxan, adriamycin and cis-platinum(CAP) in patients with advanced prostatic cancer. A.A.C.R. Abstracts, 198, 1980.

21) Torti, F.M., Shortliffe, L.D., Carter, S.K., Hannigan, J.F. Jr., Aston, D., Lum, B.L., WIlliams, R.D., Spaulding, J.T. and Freiha, F.S.: A randomized study of doxorubicin versus doxorubic in plus cisplatin in endocrine-unresponsive metastatic prostatic carcinoma. Cancer, 56, 2580-2586, 1985.

22) Soloway, M.S., deKernion, J.B., Gibbons, R.P., et al.: Comparison of estramustine phosphate and vincristine alone or in combination for patients with advanecd, hormone refractory, previously irradiated carcinoma of the previously irradiated carcinoma of the prostate. J. Urol., 125, 664-667, 1981.

23）斉藤 泰：前立腺癌一再燃癌の治療上の問題点. 治療, 67, 1809-1814, 1985.

24）島崎 淳, 伊藤晴夫, 宮内大成, 布施秀樹, 井坂茂 夫：前立腺癌の内分泌療法. Oncologia, 10, $82-98,1984$.

25) Huggins, C. and Scott, W.W.: Bilateral adrenalectomy in prostatic cancer. clinical features and urinary excretion of 17-ketosteroids and estrogens. Ann. Surg., 122, 1031-1041, 1945.

26）江藤耕作, 野田進士, 薬師寺道則：前立腺癌の外科 的内分泌療法について. (1)左副腎静脈中結腸静脈 
吸合術。西日泌尿，37，347-355，1975.

27）江藤耕作, 野田進士, 薬師寺道則：前立腺癌の外科 的内分泌療法。 (2)臨床統計的観察。西日泌尿，37, $356-362,1975$.

28) Maddy, J.A., Winternitz, W.W. and Norrell, H. : Cryohypophysectomy in the management of advanced prostatic cancer. Cancer, 28, 322 $-328,1971$

29) Worgul, T.J., Santen, R.J., Samojlik, E., Veldhuis, J.D., Lipton, A., Harvey, H.A., Drago, J.R. and Rohner, T.J.: Clinical and biochemical effect of aminoglutethiamide in the treatment of advanced prostatic carcinoma. J. Urol., 129, 51-55, 1983.

30) Labrie, F., Dupont, A., Emond, J. and Monfette, G. : Combination therapy in prostate cancer. Lancet, 8515, 1095-1096, 1986.

31) Mukamel, E., Nissenkorn, I. and Servedio, C. : Early combined hormonal and chemotherapy for metastatic carcinoma of prostate. Urology, 16, 257-260, 1980.

32) Servadio, C., Mukamel, E., Lurie, H. and
Nissenkorn, I. : Early combined hormonal and chemotherapy for metastatic prostatic carcinoma. Urology, 21, 493-495, 1983.

33）神田英憲, 若林 昭, 加藤良成, 片岡喜代徳, 秋山 隆弘, 栗田 孝：前立腺癌の化学内分泌療法47例 の検討。西日泌尿，48，123-127， 1986.

34）藤井昭男, 安野博彦, 川井田徳之, 中村一郎：新鮮 stage $\mathrm{D}$ 前立腺癌に対する hormone, cyclophosphamide 併用療法。第 1 報。泌尿紀要， $32 ， 1713$ $-1717,1986$.

35）碓井 亜, 長藤達生, 大隅 泰, 中村浩二, 石部知 行：前立腺癌の治療経験一ホルモン化学併用療法 打よび手術療法一。西日泌尿, 48, 378-381, 1986.

36）倉本 博, 上田豊史, 熊澤浄一, 有吉朝美, 真崎善 二郎, 長田幸夫, 尾本徹男, 森田一喜郎, 中州 肇 : 前立腺癌に対する化学療法とホルモン療法の併用 療法の近接効果, 西日泌尿, 48, 382-387, 1986.

37）竹内弘幸：前立腺癌治療に打ける基調療法として のホルモン剤と5-fluorouracil 併用長期継続投与 の効果に関する臨床的研究。泌尿紀要， 30,1703 $-1709,1984$.

（1988年 3 月 28 日受理） 